\title{
Enhancement of Learning Outcomes by Using Active Learning Technique for Engineering Graphics Course
}

\author{
${ }^{1}$ Jayant J. Pharne, ${ }^{2}$ Swapnil H. Patil, ${ }^{3}$ Nilesh C. Gaikwad \\ ${ }^{1,2,3}$ Lecturer, Department of Mechanical Engineering, R.I.T, Rajaramnagar, India \\ 1 jayant.pharne@ ritindia.edu, ${ }^{2}$ swapnilh.patil@ ritindia.edu, ${ }^{3}$ nilesh.gaikwad@ ritindia.edu
}

\begin{abstract}
This paper presents the implementation of Project Based Learning for diploma First year Mechanical Engineering students for Engineering Graphics course. Engineering Graphics course is an important basic communication tool of engineers. The concepts of graphical language are used in expressing the ideas, conveying the instructions, which are used in carrying out the jobs on the sites, shop floor. It is expected that the students should develop the idea of visualizing the actual object or part on the basis of drawings and blue prints. Traditional learning styles in classroom education are questionable and lacking in providing the necessary tools needed by the students to meet ever growing demands of industries. This paper aims to demonstrate improved student learning outcomes and increased student participation using active learning tools. The performance of the students of two consecutive batches is compared where for one batch this technique is not used and for other the technique is implemented. This consideration concludes that project-based learning is the best way to fulfil industry needs and it will facilitate students to innovatively and creatively transfer their knowledge to the real world situation.
\end{abstract}

Keywords: Active Learning Technique, Engineering Graphics, Project Based Learning

\section{INTRODUCTION}

Engineering Graphics is the basic course for the students of all branches in Diploma. Engineering Graphics is the language of engineers and is an effective way to communicate between them. There is need to develop the idea of visualizing the actual object or part on the basis of drawings. This course aims at building a foundation for the further courses related to engineering drawing and other allied courses in coming semesters. This course has no external theory exam but only Internal End Semester exam. Conventional Teaching methods often finds difficult to the students to understand the course. The course consists of number of imaginary concepts which the student finds troublesome in grasping. The student should have high ability to imagine, think creatively and observe precisely in order to learn this course. The teacher should carefully select the teaching method that would enhance the learning abilities of the students. This course has no class tests during the whole semester and hence students are likely to neglect the course and its contents. There is need of transformation in teaching and learning approaches to enhance the student's active participation in learning.

Project-based learning is a comprehensive approach to teaching and learning that is designed to engage students in the investigation of authentic problems. Students become active learners and participate in hands-on activities, while lecturers provide guidance to students during their project work. The PBL method of learning and teaching thus requires a new mindset and a change in role for both students and teachers. It is found that this method increases student motivation, and allows them to apply their theoretical knowledge in an interactive environment [1]

\section{ACTIVE LEARNING TECHNIQUE}

The teaching learning process should be in such a way that it should increase the motivation of the students. Teaching knowledge and skills by using a variety of tools and techniques will provide good learning experiences for all the students.

Active learning involves providing opportunities for students to meaningfully talk and listen, write, read, and reflect on the content, ideas, issues, and concerns of an academic subject. [2] In the traditional method of teaching, the student is in a position of passive agent in the learning process, trying to absorb the knowledge and the teacher's experiences. The use of exhibition classes, in which the teacher exposes the subject and assesses the students from the contents absorbed in lessons and during the time utilized for the study is interesting for both didacticpedagogical issues and economic-administrative issues. This is the most economical, flexible and rapid way of 
transmission of knowledge and may be used by any professional with knowledge of the subject, even those who have no pedagogical knowledge. [3] Project Based Learning can be defined as "a comprehensive perspective" that is focused on "engaging students in investigation" [4]. The Buck Institute for Education (2013) goes into even more detail by defining project-based learning as "a systematic teaching method that engages students in learning knowledge and developing 21st century competencies through an extended, student-influenced inquiry process structured around complex, authentic questions and carefully designed products and learning tasks" [5]. Both definitions emphasize the importance of creating student engagement and creating the need for inquiry within the student. The focus of PBL is to form an educational environment that is centered on the learner [6]. The process of PBL "affords authentic learning tasks grounded in the personal interests of learners" [7]. By implementing this paradigm shift into classrooms, students will come to understand that "learning is an ongoing process and there will always be new issues to be explored" [8]. Students will develop the skills to become "life-long learners" that are able to adapt to new situations and devise solutions when presented with novel problems. [9]

Students would develop a greater interest in Engineering Graphics course by using Active Learning Technique as a method for learning.

\section{NEED OF PBL TO ENGINEERING GRAPHICS}

The main problem faced by the students in learning Engineering Graphics was the difficulty in understanding the fundamental concepts. Many times students do not find the relevance of what they are being taught in the Engineering Graphics course as it has imaginary concepts like planes, projections etc. Engineering Graphics course involves drawing of the problems or components in 2D and $3 \mathrm{D}$ forms. It is seen that students find this course difficult and has a fear about learning this course. The major reason is the traditional teaching method where the teacher uses chalk and board method to solve problems. To solve the problems faced by the students during learning it is therefore necessary to plan and implement an effective technique. One such method is through the use of project based learning (PBL) within the classroom. Project based learning tends to focus more on "the doing of an activity". By using Project Based Learning within the classroom, the student can find the concepts easier to grasp and they can enjoy the learning.

\section{IMPLEMENTATION OF THE TECHNIQUE}

For Engineering Graphics course, many concepts are imaginary and it requires high ability to imagine and think precisely. Videos are considered as an effective way to present information/concepts and students find it interesting while learning. To make the imaginary concepts easier to understand, videos were shown to the students. Wooden models were also used to demonstrate the shapes and views of different objects. For the implementation of Project Based Learning We had chosen a class of sixty students of first year Mechanical Engineering. This activity is done through micro projects which is planned to be undertaken by the students at the start of the semester and submit it at the end of the semester. Completion of the micro project was blended with project based learning.

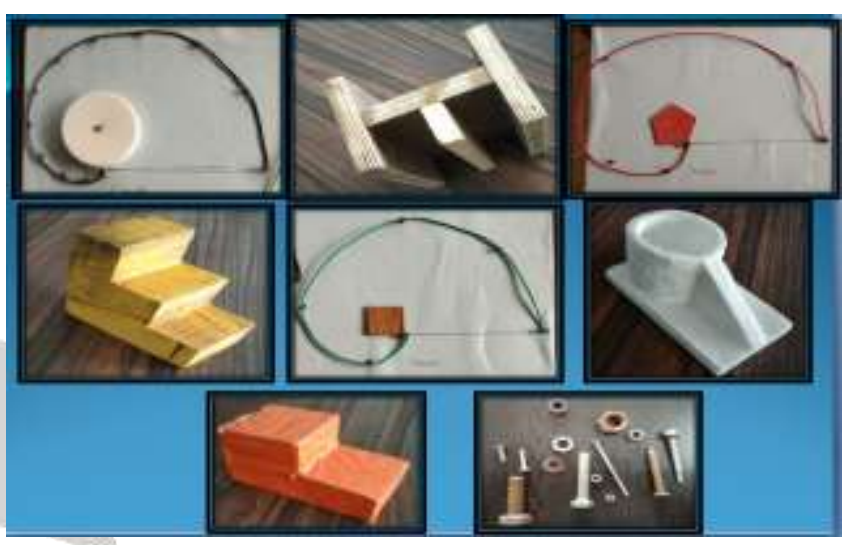

Fig 1. Some snaps of the projects prepared by the students

Following are the steps used for implementing Project Based learning:

Step 1: Formation of the groups - In the beginning of the course groups of heterogeneous students was formed to undertake the micro project.

Step 2: A suggestive list of projects is given to the students and asked to choose one of them. Each project encompasses of one or more course outcomes.

Step 3: Group members make a project plan and they choose their roles in the project.

Step 4: Group members organize and analyse the data and information required to complete the project. Individual solutions are discussed amongst the group members in order to find probable solutions. Students identify the resources they need. Students are encouraged to record their rough notes, ideas and design decisions in their logbook for their project. The logbooks are checked by the course teacher and feedback is given to students at several points during the project

Step 5: once a fortnight the project groups gives review of their project to the class and asks for suggestions if any. This makes the students to understand the projects of other groups and helps them to enhance their learning. This activity increases the active participation of the students in learning.

Step 6: Presentation is given by the group members in front of the class along with course teacher.

Step 7: Evaluation is done by the course teacher. 
Project groups have been evaluated by "Project Group Evaluation Form". Assessment rubrics were prepared to provide clear criteria of how marks are allotted in the projects.

\section{RESULT AND DISCUSSION}

With an effective implementation of project based learning approach for engineering graphics course, it is necessary to assess the effect of this hybrid model. This has been carried out through result analysis, and feedback of students.

\section{A. RESULT ANALYSIS}

Project based learning technique was implemented on 60 students of first year diploma for the batch of 2019. The results of previous year students and current year are compared to see the credibility of the technique used. It is seen that there is a meaningful difference.

Table 1. Results of End Semester Examination

\begin{tabular}{|c|c|c|}
\hline Data & & \\
\hline \multirow{3}{*}{2018} & THE HIGHEST & 40 \\
\hline & THE LOWEST & 0 \\
\hline & AVERAGE & 20 \\
\hline \multirow{3}{*}{2019} & THE HIGHEST & 46 \\
\hline & THE LOWEST & 20 \\
\hline & AVERAGE & 33 \\
\hline
\end{tabular}

The percentage of attainment of CO's is seen improved than the attainment of previous year. It can be said that project based learning approach is more effective in developing the motivations of students.

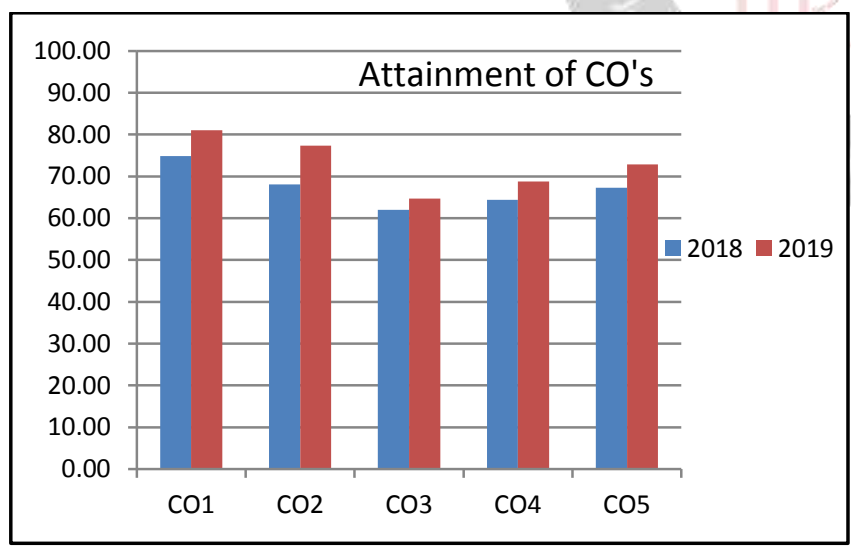

Fig 2. Attainment of CO's of two batches of students

\section{B. INSTRUCTORS' OBSERVATIONS}

It was observed that the students were enjoying the learning process. Students were having active participation in the activity. The students were excited and enthusiastic about what they are learning, they often got more involved in the course, and the level of anxiety was reduced.

\section{CONCLUSION}

Implementation of active learning technique in the class of First year Diploma has shown positive impact on the performance of the students due to its student centered approach. It allows students to get a better understanding of difficult concepts of Engineering Graphics. This technique would encourage students for their active participation in the class room activities. Students would find the learning experience and working together in groups more joyful through this Active Learning Technique.

\section{REFERENCES}

[1]Dr. Aruna Shekar, Massey University, Project based Learning in Engineering Design Education: Sharing Best Practices, 121st ASEE Annual conference and exposition, Indianapolis, IN, june 15-18, june 2014

[2]Meyer, C., \& Jones, T. B. (1993). Promoting active learning Strategies for the college classroom. San Francisco: Jossey-Bass.

[3]Eduardo Ferro dos Santos1, Bruna Caroline Marques Gonçalves2, Karine Borges de Oliveira2, Messias Borges Silva1, Project Based Learning Applied to Technical Drawing, Creative Education, 2018, 9, 479-496

[4]Blumenfeld, P., C., Soloway, E., Marx, R., W., Krajcik, J., S., Guzdial, M., Palincsar, A. (1991). Motivating project based learning: sustaining the doing supporting the learning. Educational Psychologist, 26 (3-4), 369-398.

[5]Buck Institute for Education, Boss, S., Larmer, J., \& Megendoller, J. (2013). PBL for 21st century success: teaching critical thinking, collaboration, communication and creativity. Buck Institute for Education.

[6]Grant, M. M. (2002). Getting a grip on project-based learning: Theory, cases and recommendations. Meridian: A middle school computer technologies journal, 5(1), 83 .

[7]Grant, M. (2011). Learning, beliefs, and products: Students' perspectives with project-based learning. Interdisciplinary Journal of Problem-Based Learning. 5(2), 37-69.

[8]Duch, B., Allen, D., \& White, H. (1999) Problem-based learning: preparing students to succeed in the 21st century. Teaching Matters. 3(2), $1-5$.

[9]Hmelo-Silver, C. E., \& Barrows, H. S. (2006). Goals and strategies of a problem-based learning facilitator. Interdisciplinary Journal of Problembased Learning, 1(1), 4.

[10] Wolk, S. (2001). What should we teach? the benefits of exploratory time. Educational Leadership. 59 (2), 56-59.

[11]Özge IŞIK and Berna GÜCÜM The Effect of Project Based Learning Approach on Elementary School Students' Motivation Toward Science and Technology Course, Hacettepe Üniversitesi Eğitim Fakültesi Dergisi (H. U. Journal of Education) 28(3), 206-218 [2013].

[12]Hande Alada and Hande Düzgün Bekda challenges of "Teaching and Learning" in technical drawing course: a comparison of architectural and civil engineering education Journal of Teaching and Education, CDROM. ISSN: 2165-6266 :: 08(02):1-12 (2018)

[13]Petrosina, A. 2009.Project-Based Learning: Background Knowledge and Theory. Madison:Wisconsin Center for Education Research, (Online), (http://college.Cengage.com/education/pbl/background.html), was accessed on 19 January 2012.

[14] Suparti, Project-Based Learning Guided Lesson Study Improve the Achievement of Learning Outcomes on Seminar Accounting Education Course at Department Of Accounting, IOSR Journal of Research \& Method in Education (IOSR-JRME) e-ISSN: 2320-7388,p-ISSN: 2320 737X Volume 5, Issue 3 Ver. II (May - Jun. 2015), PP 05-11

[15]Downing, K., Kwong, T., Chan, S., Lam, T., \& Downing, W. (2009). Problem-based learning and the development of metacognition. Higher Education, 57(5), 609-621.

[16]H. I. Modell, Preparing students to participate in an activelearning environment, Advan Physiol Educ 270:69-77, 1996.

[17]P. S Jadhav, D. G Thombare, P. M Jadhav, S. B Khot, Assessing the Effectiveness of a Hybrid PPBL Model of Delivering Workshop Practice Course for the First-Year Engineering Students, Journal of Engineering Education Transformations 33, 510-515. 